\begin{abstract}
Materials and Methods
Vaginal smears of five pluriparous females at least two months post partum were observed over a 90 day period. Approximately $5 \mathrm{~mL}$ of $10 \%$ saline solution was aspirated $4 \mathrm{~cm}$ deep into the cranial vagina and washed 4 times. One milliliter of the final wash was plated on a slide and observed under the microscope (at $4 \mathrm{x}$ mag). Leucocytes, nucleated, enucleated and cornified cells were identified in the swabs, in varying ratios, coinciding with the four stages of the estrous cycle.
\end{abstract}

Results and Conclusion

The estrous cycle (mean \pm SD) was found to be 31 ( \pm 4 days) with day $17( \pm 2$ days) being estrus. It was concluded that vaginal cytology is an effective method of characterizing the estrous cycle of the female agouti and confirms the findings of Guimarães (2000).

\title{
Reference
}

Guimarães DA 2000. Aspectos reprodutivos e endócrinos da puberdade, ciclo estral, gestação e cio pós-parto de cutias (Rodentia:Dasyproctidae), criadas em cativeiro. PhD Thesis, Universidade Federal do Pará. Belém, Pará, Brazil. 94 p.

\section{Dietary electrolyte balance responses in broilers reared in moderately high environmental temperature and high humidity}

\author{
Tanveer Ahmad ${ }^{1 \dagger}$, M. Sarwar ${ }^{2}$, Mahr-Un-Nisa ${ }^{2}$, Ahsan-Ul-Haq ${ }^{3}$, J. Ansari ${ }^{4}$ and Farooq Iqbal ${ }^{1}$ \\ ${ }^{1}$ Department of Livestock Production and Management, Faculty of Veterinary and Animal Sciences, PMAS-Arid Agriculture University, 46300, Rawalpindi, Pakistan; \\ ${ }^{2}$ Institute of Animal Nutrition and Feed Technology; ${ }^{3}$ Department of Poultry Sciences, University of Agriculture, Faisalabad, Pakistan, ${ }^{C}$ Department of Poultry \\ Husbandry, University of Agriculture, Faisalabad, Pakistan; ${ }^{4}$ Poultry Research Institute, Poultry Farms, Bahawalpur, Pakistan
}

\begin{abstract}
Introduction
High environmental temperature coupled with high humidity, a typical feature of monsoon season, has even more harmful effects on the performance of broilers since they feel difficulty in dissipating heat through panting. Several management techniques and dietary modifications have been employed to alleviate heat stress and improve broiler productivity. However, none of these have been considered as a perfect solution in itself. Borges et al. (2003) and Ahmad et al. (2005) employed the concept of electrolyte balance (EB) to counter heat stress in broilers. It was hypothesized that dietary uptake and proper balance of sodium, potassium and chloride can also be helpful to adjust disturbed blood acid-base balance in broilers reared during the hot and humid season. The present study was designed to determine an optimal and practical dietary EB in terms of growth performance and physiological adjustment of broilers reared during the hot and humid season.
\end{abstract}

\section{Material and methods}

A total of 216 broilers were reared up to $42 \mathrm{~d}$ in moderately high temperature and humidity. Chicks were exposed to daily cyclic heat stress

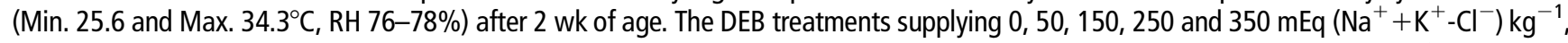
were prepared by adding $\mathrm{NaHCO}_{3}$ and/or $\mathrm{NH}_{4} \mathrm{Cl}$ to the basal diet without altering $\mathrm{K}$ contents $(0.71$ and $0.65 \%$ in starter and finisher diets, respectively). Basal starter $\left(185 \mathrm{mEq} \mathrm{kg}^{-1}\right)$ and finisher $\left(172 \mathrm{mEq} \mathrm{kg}^{-1}\right)$ diets containing $\mathrm{NaCl}$ were served as the control. Each diet was randomly offered to three experimental units having 12 chicks each. The data on live bird performance, water temperature, $\mathrm{pH}$ and consumption, rectal temperature, litter moisture, mortality, carcass characteristics, and blood analysis was collected.

\section{Results}

The DEB 50 and $250 \mathrm{mEq} \mathrm{kg}^{-1}$ significantly $(P<0.05)$ improved the body weight gain, feed intake, feed:gain ratio (Table 1) and water intake. Mortality was not influenced significantly $(P>0.05)$ by DEB treatments. DEB 50 and 250 significantly lowered the blood alkalotic pH and HCO3 concentrations as well as maintained the blood base excess values near to zero on the 43rd day. Significantly $(P<0.01)$ reduced heterophils $(H)$, increased lymphocyte $(L)$ percent, $H / L$ ratios, hemoglobin and hematocrit concentration were also noted by DEB 50 and $250 \mathrm{mEq} \mathrm{kg}^{-1}$. High blood K, Na and Cl were noticed in DEB 250, 350 and $0 \mathrm{mEq} \mathrm{kg}^{-1}$, respectively. However significantly high blood EB was noted in DEB $250 \mathrm{mEq} \mathrm{kg}^{-1}$.

\footnotetext{
${ }^{\dagger}$ E-mail: tanvirah@yahoo.com
} 
Table 1 Effect of varying dietary electrolyte balance on broiler performance reared under hot and humid environment from 1 to 42 days of age

\begin{tabular}{lccccccr}
\hline \hline & \multicolumn{7}{c}{ Dietary Electrolyte Balance $\left(\mathrm{Na}+\mathrm{K}-\mathrm{Cl} ; \mathrm{mEq} \mathrm{kg}^{-1}\right)$} \\
\cline { 2 - 6 } Parameters & Control & 0 & 50 & 150 & 250 & 350 & Pooled SEM \\
\hline Weight gain & $1602^{\mathrm{bc}}$ & $1537^{\mathrm{c}}$ & $1749^{\mathrm{a}}$ & $1655^{\mathrm{b}}$ & $1778^{\mathrm{a}}$ & $1657^{\mathrm{b}}$ & 22.4 \\
Feed Intake & $3217^{\mathrm{bc}}$ & $3162^{\mathrm{c}}$ & $3419^{\mathrm{a}}$ & $3325^{\mathrm{ab}}$ & $3437^{\mathrm{a}}$ & $3335^{\mathrm{ab}}$ & 28.9 \\
Feed:Gain & $2.008^{\mathrm{b}}$ & $2.057^{\mathrm{c}}$ & $1.957^{\mathrm{a}}$ & $2.010^{\mathrm{b}}$ & $1.933^{\mathrm{a}}$ & $2.013^{\mathrm{b}}$ & 0.011 \\
\hline \hline
\end{tabular}

abc Values with different superscripts in a row differ significantly $(P<0.05)$.

\title{
Conclusions
}

The overall favorable performance achieved in this experiment indicate that with a fixed level of $\mathrm{K}^{+}(0.71$ and $0.65 \%)$, diets containing low $\mathrm{Na}^{+}(0.26$ and $0.20 \%)$, and high $\mathrm{Cl}^{-}(0.88$ and $0.71 \%)$, or high $\mathrm{Na}^{+}(0.36$ and $0.35 \%)$ and low $\mathrm{Cl}^{-}(0.32$ and $0.23 \%)$ concentrations, in the starter and finisher diets, respectively, could be used to alleviate the adverse effects of the hot and humid season.

\section{References}

Ahmad T, Sarwar M, Mahr-un-Nisa , Ahsan-ul-Haq and Zia-ul-Hasan 2005. Anim Feed Sci Technol 120, 277-298.

Borges SA, Fischer da Silva AV, Ariki J, Hooge DM and Cummings KR 2003. Poult Sci 82, 301-308.

\section{Meta-analysis of the effect of high ambient temperature on growing pig performance}

\author{
David Renaudeau ${ }^{\dagger}$ and Jean-Luc Gourdine
}

\author{
INRA UR 143, 97170 Petit Bourg, Guadeloupe, France
}

The high ambient temperature has been recognized as the most important climatic factor influencing pig performance during summer heat waves in a temperate climate and all year in a tropical climate. However, the results of experiments dealing with the effects of high temperature on pig performance are remarkably variables. In the present work, a meta-analysis was carried out to analyze the results from different studies designed to evaluate the effect of elevated temperature on average daily feed intake (ADFI) and average daily gain (ADG) in growing finishing pigs. Data were extracted from 86 and 80 trials for ADFI and ADG, respectively, from studies published in scientific journals in PubMed, Science direct and proceedings of scientific meetings updated through December 2009. Data on ADFI and ADG were analyzed with a linear mixed model that included the linear and the quadratic effects of temperature (T) and pig body weight (BW), the interaction between T and BW as covariates. The trial has been included as a block random variable. The effects of housing conditions ( $n=2$; individual vs. group) and the year of publication of the trial $(n=3 ; 1970-1989,1990-1999$, and 2000-2009) were tested on the intercept and the linear slope of T. The results show that high T had a curvilinear effect of ADFI and ADG and that this effect was highlighted in heavier pigs. Whatever the temperature level, the ADFI was lower when pigs were group-housed. The intercept and slope for T were significantly affected by the year of the study publication. The effect of elevated T was greater in earlier works suggesting that modern genotypes could be more sensitive to heat stress than low growth potential pigs. In conclusion, the results of this meta-analysis confirm that a large between-study variability exits for the effects of high T on pig performance. A part of this variability is explained by changes in pig BW range and to a lesser extent by the year of the study publication.

\footnotetext{
${ }^{\dagger}$ E-mail: david.renaudeau@antilles.inra.fr
} 